\title{
Investigations on Improving the Compressive Strength of Sand Column with Cement Grout and Chemical Admixture
}

\author{
M. Samuel Thanaraj ${ }^{1}$, C. Freeda Christy ${ }^{2}$, J. Brema $^{3}$ \\ ${ }^{1}$ Assistant professor, Nehru Institute of Technology, Coimbatore. \\ ${ }^{2}$ Associate Professor, Karunya Institute of Technology and Sciences, Coimbatore. \\ ${ }^{3}$ Professor, Karunya Institute of Technology and Sciences, Coimbatore \\ samuelthanaraj@gmail.com ${ }^{1}$, freeda@karunya.edu ${ }^{2}$, jbjeyanarayanan@yahoo.co.in ${ }^{3}$
}

Article History: Received: 10 November 2020; Revised: 12 January 2021; Accepted: 27 January 2021; Published online: 05 April 2021

\begin{abstract}
Grouting is one of the most commonly adopted technique for soil improvement and strengthening. Adding super plasticizers, accelerators, antifreezes, air entraining agent improves the performance of the cement grout. The performance of the grout while injecting in the sand column mainly depends on its fluidity property. Keeping it in mind about the water cement ratio, the strength of the sand column is studied in two sets of experiments one by sand column with cement grout only and another set by sand column with cement grout added with super plasticizers by varying the water cement ratios. Strength parameters like angle of internal friction and cohesion were obtained be direct shear test and unconfined compressive strength test on the specimens by varying the water content. An increase of $15.2 \mathrm{kPa}$ to $60.33 \mathrm{kPa}$ was observed in the cohesion value for specimens with $10 \%$ water content and $13.8 \mathrm{kpa}$ to $47.2 \mathrm{kPa}$ cohesion value observed in the specimens with $20 \%$ water content. The angle of internal friction was decreased from $36^{0}$ to $16^{0}$ for $10 \%$ water content whereas 300 to 100 for $20 \%$ water content. A series of experiments were conducted on the sand column grouted with cement and for different water cement ratios as 1.5, 2.0 and 2.5. Another set of experiments were repeated by adding 2\%super plasticizer Sulphonated Melamine Formaldehyde (SMF). The experiment results revealed that at lower water cement ratio higher value of compressive strength was observed. It was also observed that the strength increases with curing period.
\end{abstract}

Keywords: Grouting, Compressive Strength, Super Plastisizer.

\section{Introduction}

Grouting technique is adopted very widely in various purposes especially in soil strengthening by injecting the grout to seal voids, filling fissures and cavities in rocks also. By sealing the pores it helps in reducing the permeability. Grouting has a wide application in modern civil engineering world (Nonveiller 1989) to strengthen the dam structures, increasing the strength of the soil under the foundation, fixing and sealing of soil nailing adopted in slope stability works, fixing reinforcing elements (e.g. cables) in pre-stressed concrete structures, Repair and rehabilitation of deteriorated structures and buildings, Fill voids between rock and tunnel linings (yasilinacur, 2003), rehabilitate and reinforce old defective masonry of historical buildings (Yeon and Han, 1997) fixing reinforcing elements (e.g. cables) in pre-stressed concrete structures, lifting and erection of leaning structures and buildings, Fill voids between rock and tunnel linings (yasilinacur, 2003), rehabilitate and reinforce old defective masonry of historical buildings (Yeon and Han, 1997).

\section{Scope and Objective}

Sand column being one of the methods of installing vertical drains to reduce the water table, could also be adapted to strengthening measures for weak soil stabilization by injecting cement or lime as grout by increasing its compressive strength and by increasing the surrounding soil on installation. The following objectives were considered in this experimental study:

1. To study the improvement in the compressive strength of sand column with grout by varying the water cement ratios for its fluidity characteristics to ease injection.

2. To bring out the extent of improvement in adding super plasticizer. 

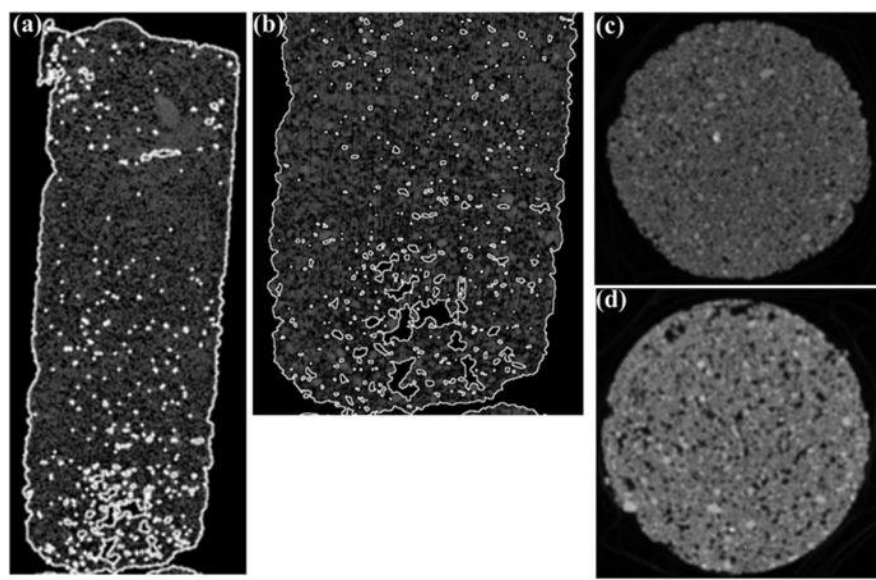

Figure 1. Courtesy Images Showing Grouted Sand Columns

\section{Experimental Methodology}

1. Properties of materials

Sand, Cement and Super Plasticizer (SMF)

2. Experimental Programme

1. Specimen Sample preparations with different water cement ratios

2. Shear strength parameters from Direct shear test and Unconfined compressive strength test

3. Results and discussions

4. Conclusion.

\section{Properties of Materials}

\subsection{Properties of Cement}

Ordinary Portland cement (OPC) is used for this investigation. Laboratory tests were conducted and the following values obtained. Specific gravity $(G)$ as 3.15 , Initial setting time 30 minutes and final setting time 300 minutes.

\subsection{Properties of Sand}

River sand was collected from Cauvery River, near Karur district of Tamilnadu for testing. From the grain size distribution curve, the values obtained for the sand is listed in table. Direct shear test was conducted and the angle of internal friction is found to be $35^{\circ}$.

Table 1. Properties of Sand

\begin{tabular}{|c|c|c|}
\hline S.No. & Description & Values \\
\hline 1 & IS classification & $\begin{array}{c}\text { SP } \\
\text { (USBR1960) }\end{array}$ \\
\hline & D10 Effective size & $0.24 \mathrm{~mm}$ \\
\hline 2 & D60 & $0.74 \mathrm{~mm}$ \\
\hline 3 & Uniformity Coefficient & 2.90 \\
\hline 4 & Coefficient of curvature & 0.95 \\
\hline 5 & Minimum dry density & $1.58 \mathrm{~g} / \mathrm{cc}$ \\
\hline 6 & Maximum dry density & $1.64 \mathrm{~g} / \mathrm{cc}$ \\
\hline 7 & Test density & $1.60 \mathrm{~g} / \mathrm{cc}$ \\
\hline 8 & Angle of internal friction & $35^{0}$ \\
\hline
\end{tabular}




\subsection{Properties of SMF}

Sulphonated melamine Formaldehyde (SMF) is a high range water reducer referred commonly as super plasticizer. It confines the requirement of chemical admixtures specification for concrete GB $8076-1987$

Table 2. Properties SMF

\begin{tabular}{|c|c|c|}
\hline Sl.No & Properties & Characteristic value \\
\hline 1 & Visual appearance & White Liquid \\
\hline 2 & $\mathrm{pH}$ value & $8-9$ \\
\hline 3 & Chloride content (\%) & $0.03-0.04$ \\
\hline 4 & So4 content $(\%)$ & $3-4$ \\
\hline 5 & Density & 1.2 \\
\hline 6 & Surface tension $(\mathrm{N} / \mathrm{cm})$ & $(71+/-0.2) \times 105$ \\
\hline 7 & Solid content $(\%)$ & 92 \\
\hline
\end{tabular}

\section{Experimental Programme}

\subsection{Sample preparation for Direct shear test}

Sample preparation for direct shear test (undrained) with different water cement ratios as listed in the table:

Table 3. Sample Preparations for Direct Shear Test

\begin{tabular}{|c|c|c|}
\hline \multirow{3}{*}{ Set } & $\begin{array}{c}\text { Cement } \\
\text { Content } \%\end{array}$ & Water content \% \\
\hline \multirow{4}{*}{ I } & 2 & 10 \\
\cline { 2 - 3 } & 4 & 10 \\
\cline { 2 - 3 } & 6 & 10 \\
\cline { 2 - 3 } & 8 & 10 \\
\hline \multirow{4}{*}{ II } & 2 & 20 \\
\cline { 2 - 3 } & 4 & 20 \\
\cline { 2 - 3 } & 6 & 20 \\
\cline { 2 - 3 } & 8 & 20 \\
\hline
\end{tabular}

\subsection{Sample preparation for UCC test}

The success of grouting mainly depends upon the efficiency of grout to occupy void space and then bind the particulate material. If the cement is mixed with water to use as a grout, then this is in the form of suspension grout. The workability of suspension grout to occupy the void space increases with increase in amount of water. But if the water content is more, then the strength of the grouted sand column decreases. In order to have better workability and also to have higher strength super plasticizer are used.

Hence the second set of experiments are focused to get the unconfined compressive strength of sand column grouted with different cement of water cement ratio without super plasticizer and with $2 \%$ of super plasticizer/admixture. The various percentages of cement contents used to stabilize the sand are 2,4 , and 8 at water contents $10 \%$ and $20 \%$. Effects of curing period on strength of the stabilized soil are brought by curing the samples for curing periods of 7, 14 and 28 days.

Table 4. Sample Preparation for UCC Test

\begin{tabular}{|c|l|l|l|l|l|}
\hline \multirow{4}{*}{ Sets } & $\begin{array}{c}\text { Water } \\
(\mathrm{ml})\end{array}$ & $\begin{array}{c}\text { Cement } \\
(\mathrm{g})\end{array}$ & ratio & $\begin{array}{c}\text { SMF } \\
(\%)\end{array}$ & $\begin{array}{c}\text { Curing } \\
(\text { days })\end{array}$ \\
\hline \multirow{4}{*}{$\mathrm{I}$} & 150 & 100 & 1.5 & & 7 \\
\cline { 2 - 6 } & 150 & 100 & 1.5 & & 14 \\
\cline { 2 - 6 } & 150 & 100 & 1.5 & & 28 \\
\cline { 2 - 6 } & 150 & 100 & 1.5 & 2 & 7 \\
\hline
\end{tabular}




\begin{tabular}{|l|l|l|l|l|l|}
\hline \multirow{5}{*}{} & 150 & 100 & 1.5 & 2 & 14 \\
\cline { 2 - 6 } & 150 & 100 & 1.5 & 2 & 28 \\
\hline \multirow{5}{*}{ II } & 200 & 100 & 2.0 & & 7 \\
\cline { 2 - 6 } & 200 & 100 & 2.0 & & 14 \\
\cline { 2 - 6 } & 200 & 100 & 2.0 & & 28 \\
\cline { 2 - 6 } & 200 & 100 & 2.0 & 2 & 7 \\
\cline { 2 - 6 } & 200 & 100 & 2.0 & 2 & 14 \\
\cline { 2 - 6 } & 200 & 100 & 2.0 & 2 & 28 \\
\hline \multirow{5}{*}{ III } & 250 & 100 & 2.5 & & 7 \\
\cline { 2 - 6 } & 250 & 100 & 2.5 & & 14 \\
\cline { 2 - 6 } & 250 & 100 & 2.5 & & 28 \\
\cline { 2 - 6 } & 250 & 100 & 2.5 & 2 & 7 \\
\cline { 2 - 6 } & 250 & 100 & 2.5 & 2 & 14 \\
\cline { 2 - 6 } & 250 & 100 & 2.5 & 2 & 28 \\
\hline
\end{tabular}

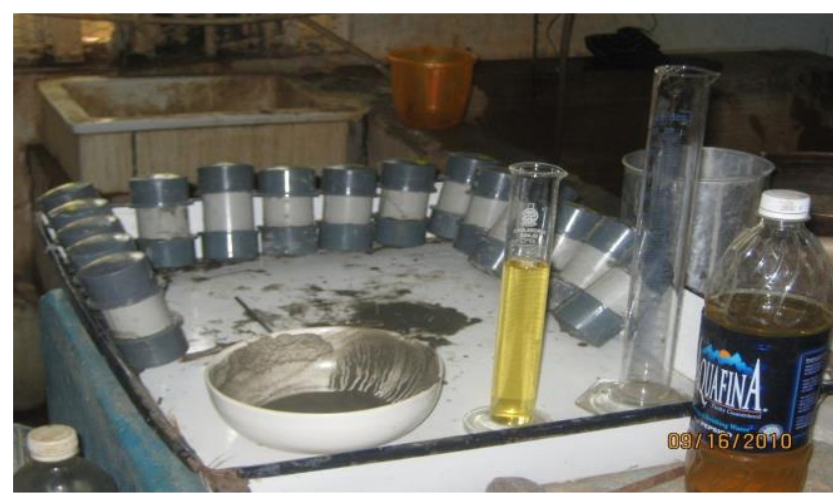

Figure 2. Sample Preparation of Sand Columns for UCC Test

A split mould has been prepared to cast the soil specimen for UCC test by keeping the 1/d ratio 1:2 as diameter $45 \mathrm{~mm}$ and height $90 \mathrm{~mm}$ with cap at both ends having a hole at top and bottom to allow the grout to pass freely from top to bottom. The mould is filled with sand and the grout is allowed to pass from top until it reaches the bottom. After curing for 7 days, 14 days and 28 days respectively the soil specimen was extracted from the split mould for UCC test.

\section{Results and Discussions}

\subsection{Shear strength parameters $(c \& \varphi)$}

The values of angle of internal friction obtained from direct shear test immediately after preparation sand with cement and water in various mix ratios as tabulated in table 3 are plotted in the graph to represent the variations due the effect of different mix proportions.

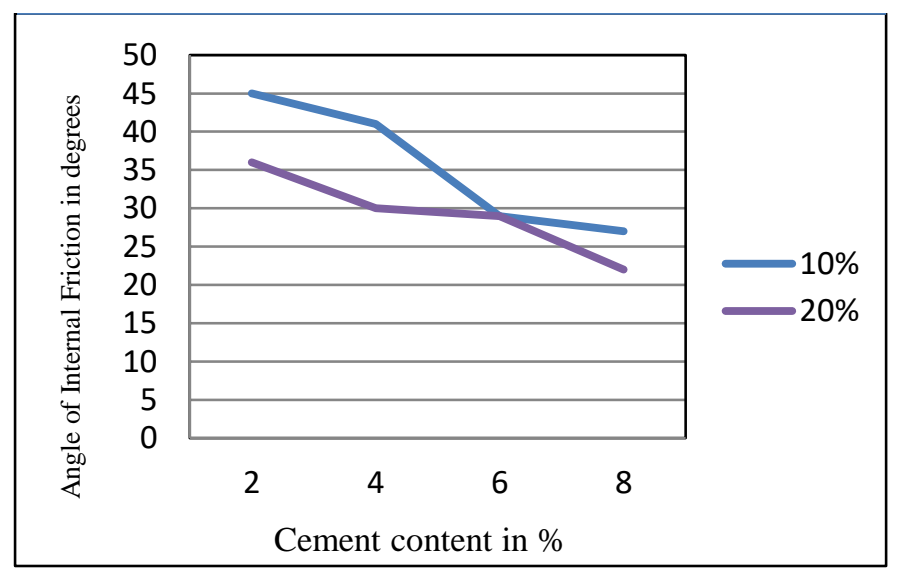

Figure 3. Effect of Cement Content on Angle of Internal Friction 
It is observed that as the angle of internal friction decrease with an increase of cement content. It is also observed that the rate of reduction in angle of internal friction with variation of cement content from $2 \%$ as $45^{\circ}$ to $8 \%$ as $27^{\circ}$ for $10 \%$ water content. Whereas for $20 \%$ water content, there is a change in the values of angle of internal friction from $36^{\circ}$ for $2 \%$ cement and $22^{\circ}$ for $8 \%$ cement mixed specimens.

The variation of cohesion as obtained from direct shear test with increase in water cement ratio is plotted in figure 4 .

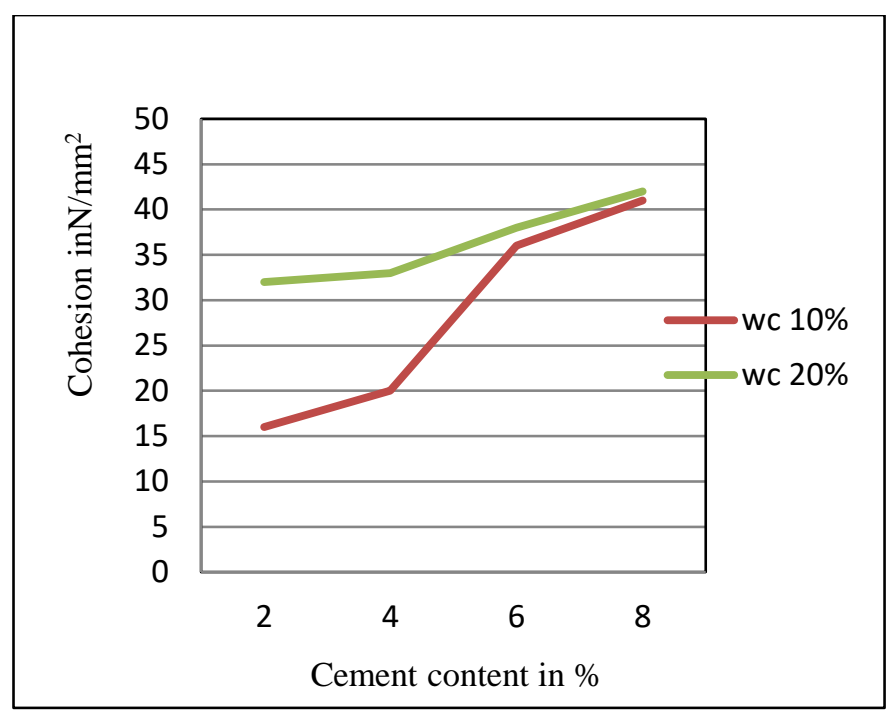

Figure 4. Effect of Cement Content on Angle of Internal Friction

The observed values of cohesion from direct shear tests with an addition of cement content by two sets, one with $10 \%$ water content and another with $20 \%$ water content is shown in fig 4 . It is noted that there is an increase in cohesion with increase in cement content from $16 \mathrm{~N} / \mathrm{mm}^{2}$ from $2 \%$ cement content and $41 \mathrm{~N} / \mathrm{mm}^{2}$ for $8 \%$ cement content for $10 \%$ water. An increase from $32 \mathrm{~N} / \mathrm{mm}^{2}$ from $2 \%$ cement and $42 \mathrm{~N} / \mathrm{mm} 2$ has been recorded for $20 \%$ water content. This may be due the increase in grout fluid property enabled the mixing of cement paste with sand grains more compared with $10 \%$ of water content.

\subsection{Unconfined Compressive Strength (UCC)}

The unconfined compressive strength of grouted sand columns were conducted on the specimens as shown in table 4 after the curing periods of 7 days, 14 days and 28 days respectively. The variation of UCC values are plotted in the graph shown in figure 5 for the sand columns grouted with cement only and the variation of UCC values for sand columns with cement plus $2 \%$ super plasticizer SMF in figure 6.

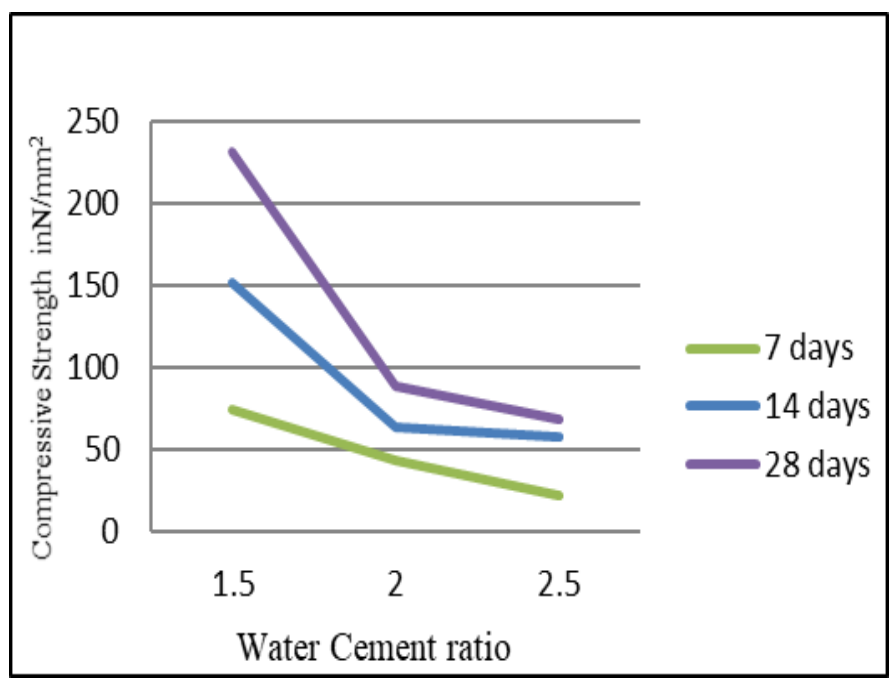

Figure 5. Variation of Compressive Strength of Sand Column Specimen with Cement Grout Only 
Table 4. UCC Strength of cement grouted sand specimen

\begin{tabular}{|c|c|c|c|c|}
\hline Sl.No & W/C ratio & $\begin{array}{c}7 \text { days } \\
\mathrm{N} / \mathrm{mm}^{2}\end{array}$ & $\begin{array}{c}14 \text { days } \\
\mathrm{N} / \mathrm{mm}^{2}\end{array}$ & $\begin{array}{c}28 \text { days } \\
\mathrm{N} / \mathrm{mm}^{2}\end{array}$ \\
\hline 1 & 1.5 & 74.19 & 152.44 & 231.52 \\
\hline 2 & 2 & 43.38 & 64.23 & 88.54 \\
\hline 3 & 2.5 & 21.81 & 58.03 & 68.86 \\
\hline
\end{tabular}

The grouted specimens with low water cement ratio exhibits a remarkable increase in UCC strength for all curing intervals whereas the increase of water content showed a lesser values for the grouted sand columns with cement only.

Table 6. UCC Strength of cement grouted sand specimen with $2 \%$ super plasticizer SMF

\begin{tabular}{|c|c|c|c|c|}
\hline Sl.No & $\begin{array}{c}\text { Water } \\
\text { cement } \\
\text { ratio }\end{array}$ & $\begin{array}{c}7 \text { days } \\
\mathrm{N} / \mathrm{mm}^{2}\end{array}$ & $\begin{array}{c}14 \text { days } \\
\mathrm{N} / \mathrm{mm}^{2}\end{array}$ & $\begin{array}{c}28 \text { days } \\
\mathrm{N} / \mathrm{mm}^{2}\end{array}$ \\
\hline 1 & 1.5 & 276.27 & 389.05 & 451.83 \\
\hline 2 & 2 & 74.19 & 143.91 & 225.06 \\
\hline 3 & 2.5 & 50.81 & 72.16 & 81.72 \\
\hline
\end{tabular}

Figure 6 shows the increase of unconfined compressive strength with cement grout added with super plasticizer Sulphonated Melamine Formaldehyde for the curing periods of 7, 14 and 28 respectively. The UCC strength values are increased with the curing time similar to the specimens grouted with cement alone but a drastic increase has been observed in the case of sand columns grouted with cement plus super plasticizer as listed in Table 6. The sand columns grouted with lower water cement ratio performs well compared with the other proportions.

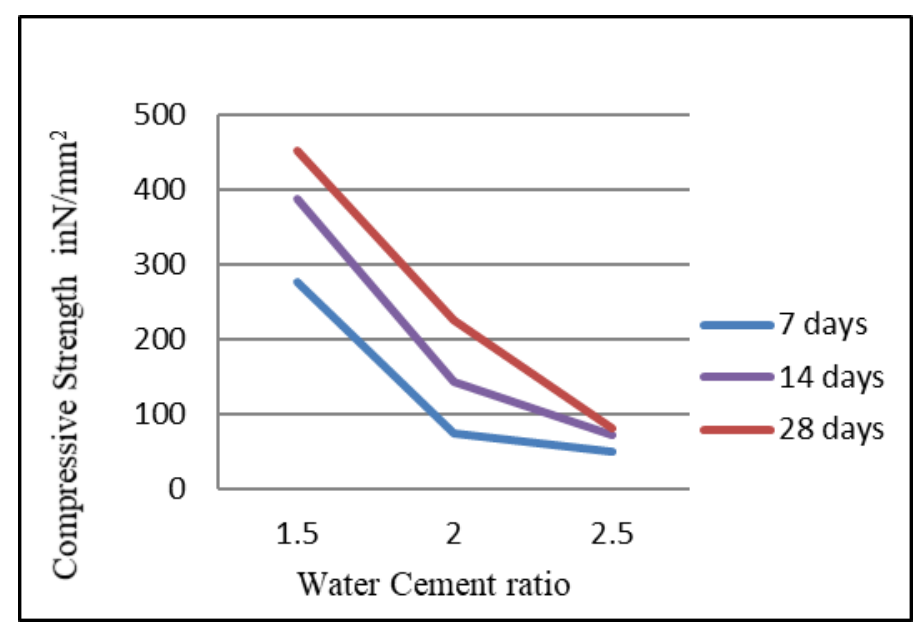

Figure 6. Variation of compressive strength of sand column specimen with cement grout only

It is inferred that adding SMF with cement grout is very effective in improving the strength in lower water content ratio. Addition of $2 \%$ SMF has improved the workability and facilitated the grout at lower water cement ratio to fill the voids easily.

\section{Summary and Conclusion}

On the experimental study conducted, the following conclusions were obtained on the sand column specimens with cement grout added with super plasticizer SMF.

- The value of angle of internal friction decreases with the increased percentage of Cement and water.

- The compressive strength of grouted sand column decreased linearly with increased percentage of water cement ratios whereas the sand columns grouted with cement plus super plasticizer SMF showed an increased values when compared with sand columns grouted with cement alone in all water cement ratios.

- $\quad$ The addition of super plasticizer SMF is very effective at all water cement ratios which in turn will improve the compressive strength which behave well in weak soil stabilizations. 
- As this method of installing sand columns grouted with cement plus super plasticizer is very effective and economical, this could be adopted for weak soil stabilization techniques.

\section{References}

1. Anagnotopoulos CA. (2003) 'Laboratory study of an grout injected granular soil with polymer grouts', Tunneling and Underground Space Technology, Vol.20, pp 525-533.

2. Anagnotopoulos CA. (2009) 'Cement Clay grouts modified with AR or MMA - Physical and Mechanical properties', Construction and building materials Vol.29, pp 330-343.

3. A.S.T.M Standard PA D4320 - 93 (2000) 'Standard Test Method for Laboratory Preparation of Chemically Grouted Sand Specimens for Obtaining Strength Parameters', A.S.T.M Internationals, West Conshohocken, PA

4. Ata. A and Vipulanandan C (1999) 'Factors affecting mechanical and creep properties of silicate grouted sands', Journal of Geotechnical and Geoenvironmental Engineering, Vol. 125,pp 868-876.

5. Allan M.L (1997) 'Rheology of Latex Modified grouts' cement and concrete research' Vol.27, pp1875-1884

6. Banfil P.F.G and swift D.S., 92004) 'The effect of mixing on the theology of cement based materials containing the performance super plasticizers', Annual Transactions on the Nordic Rheology society, Vol.12, pp, 9-12.

7. Bell F.G. 1993, 'Engineering treatment of soils', Department of Geology and Applied Geology, University of Natal, Durban.

8. Dano C., Hicher P.Y., and Tailez S., 'Engineering properties of grouted sands' JGGEE, ASCE, Vol.130, No.3 pp 328-338

9. A. Mohan, V.Saravana Karthika , J. Ajith , Lenin dhal, M. Tholkapiyan , "Investigation on ultra high strength slurry infiltrated multiscale fibre reinforced concrete", Materials Today : Proceedings, Volume 22, 904-911, 2020.

10. Gopalakrishnan, R., Mohan, A., Sankar, L. P., \& Vijayan, D. S. (2020). Characterisation On Toughness Property Of Self-Compacting Fibre Reinforced Concrete. In Journal of Environmental Protection and Ecology (Vol. 21, Issue 6, pp. 2153-2163).

11. Lavanya Prabha, S., Gopalakrishnan, M., Neelamegam, M., Development of high-strength nanocementitious composites using copper slag, ACI Materials Journal, 2020, 117(4), pp. 37-46.

12. Tholkapiyan, A.Mohan, Vijayan.D.S, A survey of recent studies on chlorophyll variation in Indian coastal waters, IOP Conf. Series: Materials Science and Engineering 993 (2020) 012041, 1-6.

13. R. Gopalakrishnan, VM Sounthararajan, A. Mohan, M. Tholkapiyan, "The strength and durability of flyash and quarry dust light weight foam concrete", Materials Today : Proceedings, Volume 22, $1117-1124,2020$.

14. Dhayachandhran K S, Jothilakshmi M, Tholkapiyan M, Mohan A, "Performance Evaluation and RValue for Thermally Insulated Wall With Embedding Fluted Sheets", Materials Today: Proceedings, ISSN: 1904-4720, Volume 22, 912-919, 2020

15. Lavanya Prabha, S., Dattatreya, J.K., Neelamegam, M., ,Investigation of bolted RPC plate under direct tension, Journal of Structural Engineering (Madras), 2009, 36(5), pp. 333-341

16. Prabha, S.L., Surendar, M., Neelamegam, M., Experimental investigation of eco-friendly mortar using industrial wastes, Journal of Green Engineering, 2019, 9(4), pp. 626-637 